\title{
Determinan Perilaku Keselamatan Kerja: Peran Faktor Personal Penjamah Makanan di Warung Lesehan Malioboro
}

\author{
Anita Sulistyorini ${ }^{*}$, Mohammad Zen Rahfiludin' ${ }^{2}$, and Suroto ${ }^{3}$ \\ ${ }^{1,2,3}$ Fakultas Kesehatan Masyarakat, Universitas Diponegoro \\ *E-mail:anitasulistyorini.ns@gmail.com
}

\begin{abstract}
Safety behavior has become a vital factor in reducing and even preventing work accidents. Although many studies have examined safety behavior and the factors that influence it, including personal and situational factors, the study is limited to formal industries with high risk. Besides, empirically individual elements have been shown to have a more significant influence on safety behavior. Therefore, this study aims to describe the safety behavior and the personal factors that influence it, which include the safety knowledge, safety attitudes, and safety motivation of food handlers at Warung Lesehan Malioboro. This study involved randomly 110 food handlers at Warung Lesehan Malioboro. Collecting data in this study used a questionnaire technique to measure the safety knowledge, safety attitudes, safety motivations, and safety behaviors of food handlers. Data analysis used descriptive statistics, t-test, $F$-test, and coefficient of determination (adjusted $R 2$ ). These study findings showed that the description of the factors of safety knowledge, safety attitudes, safety motivations, and safety behaviors of food handlers with good enough quality. Also, partially, the safety knowledge, safety attitudes, and safety motivation were proven to influence the work safety behavior of food handlers. Simultaneously, the factors of safety knowledge, safety attitudes, and safety motivation also affect the work safety behavior of food handlers. The contribution of these three determinant factors had an influence of $66 \%$ on the work safety behavior of food handlers at Warung Lesehan Malioboro.
\end{abstract}

Keywords : safety motivation, safety knowledge, safety behavior, sefety attitude

\begin{abstract}
Abstrak
Perilaku keselamatan telah menjadi faktor vital untuk mengurangi dan bahkan mencegah terjadinya kecelakaan kerja. Meskipun telah banyak studi yang mengkaji perilaku keselamatan dan faktor-faktor yang mempengaruhinya yang meliputi faktor personal dan situasional, namun studi tersebut terbatas pada industri formal dengan resiko yang tinggi. Selain itu, secara empiris faktor personal terbukti memiliki pengaruh yang lebih besar pada pembentukan perilaku keselamatan. Oleh karena itu, studi ini bertujuan untuk mengetahui gambaran perilaku keselamatan dan faktor personal yang mempengaruhinya yang meliputi pengetahuan, sikap, dan motivasi keselamatan para penjamah makanan di Warung Lesehan Malioboro. Studi ini melibatkan secara acak 110 penjamah makanan di Warung Lesehan Malioboro. Pengumpulan data dalam studi ini menggunakan teknik kuesioner untuk mengukur pengetahuan, sikap, motivasi, dan perilaku keselamatan penjamah makanan. Analisis data menggunakan statistik deskriptif, uji t, uji F, dan koefisien determinsi (Adjusted $R^{2}$ ). Hasil studi menunjukkan bahwa gambaran faktor pengetahuan, sikap, motivasi, dan perilaku keselamatan para penjamah makanan berketgori cukup baik. Selain itu, secara parsial faktor pengetahuan, sikap, dan motivasi keselamatan terbukti mempengaruhi perilaku keselamatan kerja para penjamah makanan. Secara simultan, faktor pengetahuan, sikap, dan motivasi juga mempengaruhi perilaku keselamatan kerja para penjamah makanan. Kontribusi ketiga faktor determinan yang terdiri dari pengetahuan, sikap, dan motivasi memberikan pengaruh sebesar $66 \%$ terhadap perilaku keselamatan kerja para penjamah makanan di Warung Lesehan Malioboro.
\end{abstract}

Kata kunci : motivasi keselamatan, pengetahuan keselamatan, perilaku keselamatan, sikap keselamatan 


\section{Pendahuluan}

Kajian kecelakaan kerja di berbagai industri merupakan proses penting dalam mengembangkan

kebijakan pencegahannya[1]. Bahkan perilaku keselamatan kerja diyakini telah menjadi faktor kunci untuk mengurangi dan bahkan mencegah terjadinya kecelakaan kerja[2]. Meningkatnya angka kecelakaan kerja disebabkan oleh rendahnya perilaku keselamatan di tempat kerja. Pekerja masih menganggap bahwa implementasi perilaku keselamatan akan menurunkan produktivitas kerja mereka. Padahal, penerapan perilaku keselamatan kerja selain memberikan dampak pada upaya pencegahan terjadinya kecelakaan kerja juga berdampak pada peningkatan produktivitas kerja jika dilakukan dengan komitmen yang baik.

Sejauh ini, penelitian tentang perilaku keselamatan kerja banyak dilakukan pada industri formal yang memiliki tingkat resiko kerja tinggi[3]-[6]. Sementara itu, penelitian perilaku keselamatan kerja di industri informal dengan resiko kerja yang rendah belum banyak dilakukan. Padahal sektor inidustri ini tidak luput dari kasus-kasus kecelakaan kerja.

Salah satu industri informal yang perlu mendapatkan perhatian dalam pengembangan perilaku keselamatan kerja yaitu pedagang kaki lima seperti Warung Lesehan Malioboro. Letak operasional sektor ini sangat strategis karena berada pada area wisata Malioboro Yogyakarta. Wisata Malioboro telah luas dikenal oleh wisatawan lokal maupun internasional, sehingga jaminan keamanan pangan dan resiko akibat pekerjaan harus diperhatikan agar memberikan kepuasan bagi para wisatawan.

Perilaku keselamatan kerja yang perlu diterapkan bagi penjamah makanan yaitu seperti penyimpanan bahan baku, pengolahan makanan, dan penyajian makanan demi menjaga keamanan pangan dan kesehatan konsumen. Secara empiris, kasus kecelakaan kerja yang sering terjadi pada juru masak seperti terpapar dengan wajan atau penggorengan panas, meningkatkan risiko luka bakar, dan tergelincir serta jatuh karena kelembaban di lantai dapur[7]-[9].

Penyebab utama terjadinya kasus kecelakaan kerja pada umumnya dipengaruhi oleh faktor personal dan situasional namun faktor personal diyakini memiliki pengaruh lebih besar. Hal ini sesuai dengan temuan studi sebelumnya yang menyatakan bahwa faktor yang mempunyai pengaruh lebih kuat dalam proses perubahan perilaku adalah faktor individual[10]. Beberapa contoh faktor personal yang memiliki peran penting yaitu seperti pengetahuan, sikap, dan motivasi keselamatan kerja [11]-[15].

Menurut Maulidhasari[16] bahwa pengetahuan menjadi dasar terhadap konsistensi perilaku seseorang, selain itu juga dijelaskan bahwa pengetahuan menentukan perilaku seseorang. Temuan ini serupa dengan teori Notoatmodjo[17] yang menyatakan bahwa perilaku yang akan bertahan lama adalah perilaku yang didasari oleh pengetahuan, kesadaran, dan sikap yang positif.

Studi sebelumnya juga mengungkapkan bahwa faktor sikap juga berperan penting dalam membentuk perilaku individu. Secara teoritis, sikap terbentuk dari pengalaman seseorang yang mempengaruhi respon terhadap semua obyek, yang diwujudkan dalam keadaan siap yang berupa mental[18]. Sikap keselamatan dapat diartikan sebagai kesiapan serta kesediaan untuk bertindak dan melaksanakan segala pelaksanaan kerja yang sesuai dengan ketentuan keselamatan dan kesehatan kerja[18]. Dalam definisi lain sikap diartikan pernyataan evaluatif yang menyenangkan maupun tidak menyenangkan terhadap individu, objek, atau suatu peristiwa yang mencerminkan perasaan seseorang terhadap sesuatu[19].

Faktor penting lainnya yaitu motivasi keselamatan. Motivasi keselamatan diyakini secara empiris mampu mempengaruhi perilaku keselamatan kerja[20], [21]. Motivasi adalah proses pengambilan keputusan dimana individu memilih hasil yang diinginkan dan menggerakkan perilaku yang sesuai untuk 
memperolehnya[22]. Sama halnya menurut Duncan [23], motivasi adalah usaha untuk mempengaruhi perilaku seseorang dalam meningkatkan tujuan organisasi semaksimal mungkin. Sementara itu, definisi motivasi keselamatan kerja yaitu kemauan seseorang untuk mengerahkan usaha untuk berperilaku selamat[24]. Penelitian sebelumnya menunjukkan bahwa motivasi keselamatan mempunyai pengaruh terhadap perilaku keselamatan kerja[25].

Mengacu pada basis data tentang perilaku keselamatan kerja khususnya pada permasalahan di sektor usaha informal Warung Lesehan Malioboro, maka perlu dilakukan penelitian atau kajian studi tentang pentingnya perilaku keselamatan dan faktorfaktor yang mempengaruhinya. Secara khusus, studi ini bertujuan untuk mengetahui gambaran faktor pengetahuan, sikap, motivasi, dan perilaku keselamatan kerja para penjamah makanan di Warung Lesehan Malioboro. Selain itu, studi ini bertujuan untuk menganalisis pengaruh faktor pengetahuan, sikap, dan motivasi keselamatan terhadap perilaku keselamatan kerja baik secara parsial maupun simultan. Terakhir, studi ini bertujuan untuk mengetahui besaran determinan pengetahuan, sikap, dan motivasi dalam mempengaruhi perilaku keselamatan kerja para penjamah makanan di Warung Lesehan Malioboro. Hubungan antar variabel pada penelitian ini ditunjukkan pada gambar 1 .

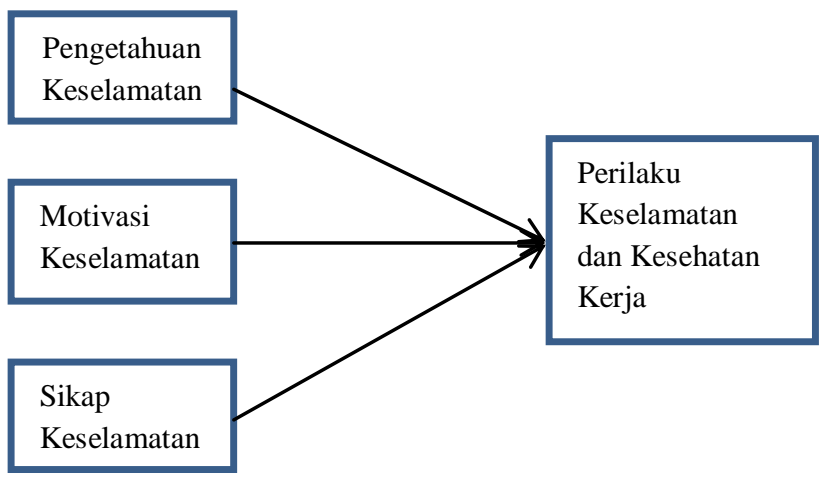

Gambar 1. Kerangka Berfikir

\section{Metoda Penelitian}

Studi ini melibatkan penjamah makanan di Warung Lesehan Malioboro, YogyakartaIndonesia sebagai responden. Sebanyak 110 responden terlibat dalam pengisian kuesioner.

Instrumen penelitian diadaptasi dan dikembangkan dari penelitian sebelumnya. Instrumen yang dikembangkan divalidasi ulang oleh expert judment. Instrumen pengetahuan keselamatan diadaptasi dan dikembangkan dari Hafrida [27], sikap keselamatan dari Muhammadfam, et al[28], motivasi keselamatan dari Shin, Gwak, dan Lee[25] dan Griffin \& Neal[29], terakhir perilaku keselamatan dari Shin et al.[25] dan Griffin \& Neal[29]. Masing-masing isntrumen memiliki nilai alpha Cronbach 0.76, 0.84, 0.72 , dan 0.74 .

Analisis data dalam studi ini menggunakan software SPSS version 21 untuk menganalisis statistik deskriptif setiap variabel dengan tiga kategori yaitu baik, cukup baik, dan kurang baik[30]. Analisis ini digunakan untuk mengetahui gambaran capaian setiap variabel. Selain itu, untuk mengetahui pengaruh variabel independen secara individu pada variabel dependen menggunakan analisis uji t. Kriteria pengambilan keputusan uji hipotesis dengan ketentuan jika p-value $<0.05$ maka hipotesis diterima. Selanjutnya, untuk mengetahui pengaruh secara simultan variabel independen terhadap variabel dependen menggunakan uji F. Kriteria pengambilan keputusan uji hipotesis dengan ketentuan jika p-value $<0.05$ maka hipotesis diterima. Terakhir, untuk mengetahui kontribusi pengetahuan, sikap, dan motivasi terhadap perilaku keselamatan menggunakan uji koefisien determinasi (Adjusted $R^{2}$ ). Semakin besar atau mendekati angka 1 maka dinyatakan pengaruhnya sangat baik.

\section{Hasil dan Pembahasan Penelitian \\ 3.1. Hasil Penelitian Uji validitas dan reliabilitas}

Analisis Person Correlation dan alpha Cronbach digunakan untuk menganalisis validitas dan reliabilitas instrumen. Hasil 
mengungkapkan bahwa semua item valid $\left(0.51^{* *} \sim 0.95 * *\right)$ dan reliabel $(0.81 \sim 0.92)$ (Tabel 1). Ini menunjukkan bahwa instrumen cukup kompeten untuk mengukur pengetahuan, sikap, motivasi, dan perilaku keselamatan [31].

Table 1. Validitas dan Reliabilitas Instrumen Penelitian

\begin{tabular}{lcc}
\hline Variables (N) & Validity & Reliability \\
\hline PK (7) & $0.53^{* *} \sim 0.95^{* *}$ & 0.811 \\
\hline SK (10) & $0.65^{* *} \sim 0.82^{* *}$ & 0.917 \\
\hline MK (9) & $0.59^{* *} \sim 0.80^{* *}$ & 0.874 \\
\hline SB (9) & $0.51^{* *} \sim 0.88^{* *}$ & 0.878 \\
\hline
\end{tabular}

Keterangan: $\mathrm{PK}=$ pengetahuan keselamatan; $\mathrm{SK}=$ sikap keselamatan; $\mathrm{MK}=$ motivasi keselamatann; $\mathrm{SB}=$ perilaku keselamatan; $* *=$ signifikan pada level 0.01

\section{Analisis Statistik Deskriptif}

Analisis statistik deskriptif digunakan untuk mengetahui capaian atau gambaran faktor pengetahuan, sikap, motivasi, dan perilaku para penjamah makanan di Warung Lesehan Malioboro. Tabel 2 menunjukkan bahwa sebagian besar capaian variabel penelitian berada pada kategori cukup baik.

Tabel 2. Deskripsi Capaian Variabel

\begin{tabular}{lcccc}
\hline \multirow{2}{*}{ Kategori } & \multicolumn{4}{c}{ Frekuensi (\%) } \\
\cline { 2 - 5 } & PK & SK & MK & SB \\
\hline Baik & 0 & 16.4 & 13.6 & 14.5 \\
\hline Cukup & 86.4 & 61.8 & 70 & 69.1 \\
\hline Kurang & 13.6 & 21.8 & 16.4 & 16.4 \\
\hline Total & 100 & 100 & 100 & 100 \\
\hline
\end{tabular}

Keterangan: $\mathrm{PK}=$ pengetahuan keselamatan; $\mathrm{SK}=$ sikap keselamatan; $\mathrm{MK}=$ motivasi keselamatann; $\mathrm{SB}=$ perilaku keselamatan

\section{Pengujian Hipotesis}

Selanjutnya, tahap akhir untuk mengetahui kebermaknaan pengaruh pada masing-masing hipotesis dilakukan uji hipotesis dengan analisis regresi sederhana dan berganda. Uji regresi sederhana menggunakan uji $\mathrm{t}$ dengan kriteria pengambilan keputusan $\mathrm{p}$-value $<0.05$ maka hipotesis diterima[32]. Pada tabel 3 menunjukkan bahwa semua hipotesis pada regresi sederhana diterima dengan $\mathrm{p}$-value < 0.05. Temuan ini bermakna bahwa masing- masing variabel independen baik pengetahuan, sikap, ataupun motivasi keselamatan memiliki pengaruh pada perilaku keselamatan.

Sementara itu, pengaruh secara bersama-sama yang meliputi faktor pengetahuan, sikap, dan motivasi keselamatan terhadap perilaku keselamatan penjamah makanana diuji dengan menggunakan uji $\mathrm{F}$ dengan kriteria pengambilan keputusan $p$ value $<0.05$ maka hipotesis diterima[32]. Pada tabel 3 menunjukkan bahwa faktor pengetahuan, sikap, dan motivasi keselamatan secara simultan memiliki pengaruh yang signifikan pada perilaku keselamatan para penjamah makanan di Waruung Lesehan Malioboro.

Tabel 3. Hasil Pengujian Hipotesis (Regresi Sederhana dan Berganda)

\begin{tabular}{llll}
\multicolumn{1}{c}{ Hipotesis } & \multicolumn{1}{c}{$\begin{array}{c}\text { T- } \\
\text { Statistics }\end{array}$} & $\begin{array}{c}\text { P- } \\
\text { Values }\end{array}$ & Hasil \\
\hline $\mathrm{PK} \rightarrow \mathrm{SB}$ & 3.446 & 0.001 & Signifikan \\
\hline $\mathrm{SK} \rightarrow \mathrm{SB}$ & 5.216 & 0.000 & Signifikan \\
\hline $\mathrm{MK} \rightarrow \mathrm{SB}$ & 3.653 & 0.000 & Signifikan \\
\hline $\begin{array}{l}\mathrm{PK}, \mathrm{SK}, \mathrm{MK} \\
\rightarrow \mathrm{SB}\end{array}$ & $\begin{array}{l}70.105(\mathrm{~F}- \\
\text { statistics })\end{array}$ & 0.000 & Signifikan \\
\hline
\end{tabular}

Keterangan: $\mathrm{PK}=$ pengetahuan keselamatan; $\mathrm{SK}=$ sikap keselamatan; $\mathrm{MK}=$ motivasi keselamatann; $\mathrm{SB}=$ perilaku keselamatan

Tahap akhir untuk mengetahui kontribusi besaran pengaruh variabel independen terhadap variabel dependen digunakan uji koefisien determinasi (Adjusted $R$ Square). Tabel 4 menunjukkan bahwa besaran pengaruh pengetahuan, sikap, dan motivasi keselamatan terhadap perilaku keselamatan kerja para penjamah makanana di Warung Lesehan Malioboro yaitu sebesar $66 \%(0.655)$.

Tabel 4. Hasil Uji Determinasi

\begin{tabular}{cccc}
\hline $\mathrm{R}$ & R Square & $\begin{array}{c}\text { Adjusted R } \\
\text { Square }\end{array}$ & $\begin{array}{c}\text { Std. } \\
\text { Error }\end{array}$ \\
\hline 0.815 & 0.665 & 0.655 & 0.31 \\
\hline
\end{tabular}




\subsection{Pembahasan}

\section{Faktor Pengetahuan Keselamatan Sebagai Prediktor Perilaku Keselamatan}

Salah satu hasil penelitian ini menunjukkan bahwa pengetahuan keselamatan memberikan pengaruh yang signifikan terhadap perilaku keselamatan penjamah makanan di Warung Lesehan Malioboro. Hasil ini mempertegas studi sebelumnya yang dilakukan oleh Vinodkumar dan Bhasi (2010), hasil studinya menyatakan bahwa pengetahuan merupakan prediktor perilaku keselamatan dan kesehatan kerja bagi para pekerja. Secara teori, perilaku dibentuk melalui rangsangan atau stimulus dari luar. Salah satunya yaitu pengetahuan yang terbentuk melalui pengalaman ataupun pendidikan dan pelatihan. Seperti halnya yang diungkapkan oleh Notoatmodjo (2014a), ia mengatakan bahwa pengetahuan merupakan hasil olahan pikiran manusia terhadap stimulus. Stimulus yang dimaksud dapat berupa pengalaman maupun pendidikan.

Merujuk pada hasil analisis statistik deskriptif menunjukkan bahwa kategori hasil pengetahuan keselamatan kerja bagi penjamah makanan di Warung Lesehan Malioboro masuk dalam kategori cukup baik. Proses pembentukan pengetahuan tersebut dapat terbentuk melalui pengalaman dan pendidikan baik formal maupun non formal. Jika melalui pendidikan formal dinilai tidak banyak memberikan sumbangsih karena hampir sebagian besar penjamah makanan di Malioboro lulusan SMP (42\%) dan SMA (40\%). Artinya, muatan kurikulum pada jenjang pendidikan tersebut tidak banyak memuat tentang muatan materi keselamatan dan kesehatan kerja. Dengan demikian, proses pembentukan pengetahuan mereka dapat diperoleh melalui pendidikan non formal seperti melalui pelatihan atau penyuluhan ataupun pengalaman mereka.

Pemberian kegiatan pelatihan secara berkala akan sangat membantu para penjamah makanan untuk senantiasa menjaga dan mengembangkan pengetahuan keselamatan mereka, khususnya dalam meningkatkan kesadaran mereka terhadap pentingnya menanamkan perilaku keselamatan kerja. Kegiatan pelatihan non formal dalam bentuk penyuluhan dan sejenisnya selama ini diinisiasi oleh Paguyuban Pedagang Lesehan Malioboro (PPLM). Paguyuban ini membawahi komunitas para pedagang lesehan makanan di Malioboro. Salah satu peran dan fungsi tersebut yaitu memberikan peran penting dalam mengedukasi para penjamah makanan. Peran edukasi ini penting dilakukan untuk meningkatkan kesadaran dan pemahahan para penjamah makanan. Menurut Schrader dan Lawless (2004) bahwa meningkatkan kesadaran dan pemahaman (seperti pengetahuan) merupakan intervensi kunci untuk mempengaruhi dan meningkatkan sikap dan perubahan perilaku.

Pengetahuan keselamatan yang baik akan membantu mendorong kesadaran dan pemahaman tentang keselamatan kerja bagi para penjamah makanan. Muatan pengetahuan keselamatan yang perlu ditanamkan meliputi pemahaman penggunaan alat pelindung diri (seperti, penggunaan sepatu dan celemek), prosedur penyimpanan bahan baku, kecelakaan kerja di dapur, dan penggunaan alat pemadam api ringan. Dalam konteks ini, pemilik warung lesehan juga turut andil dalam memberikan edukasi kepada pekerjanya baik secara langsung maupun tidak langsung melalui paguyuban.

\section{Faktor Sikap Keselamatan Sebagai Prediktor Perilaku Keselamatan}

Prediktor perilaku keselamatan dan kesehatan kerja selain pengetahuan yaitu sikap keselamatan. Hasil penelitian ini menunjukkan bahwa sikap keselamatan secara langsung signifikan mempengaruhi perilaku keselamatan para penjamah makanan di Warung Lesehan Malioboro. Hasil ini bermakna bahwa untuk meningkatkan perilaku keselamatan diperlukan penguatan kesiapan mental untuk bertindak dengan memprioritaskan keselamatan kerja. Temuan ini secara mendasar mendukung pernyataan Notoatmodjo (2007) yang menyatakan bahwa sikap dianggap sebagai kesediaan individu 
untuk bertindak dan pelaksanaan motif tertentu. Pernyataan ini menggambarkan secara tersirat bahwa sikap sebagai faktor anteseden sebelum seseorang bertindak khususnya dalam konteks tindakan atau perilaku keselamatan.

Selain itu, teori sebelumnya menyatakan bahwa sikap terbentuk melalui tiga tahap yaitu perhatian, pengertian, dan penerimaan [18]. Tahap akhir dari pembentukan sikap ditandai adanya perubahan sikap sebagai bentuk reaksi dalam sebuah tindakan. Berdasarkan tahapan pembentuk sikap tersebut, maka dapat dipahami bahwa sikap keselamatan merupakan kesiapan seseorang untuk bertindak dalam konteks pelaksanaan kerja yang sesuai ketentuan keselamatan dan kesehatan kerja [18]. Inilah alasan mendasar kenapa faktor sikap keselamatan memberikan pengaruh langsung terbesar terhadap perilaku keselamatan daripada faktor pengetahuan maupun motivasi keselamatan. Alasannya yaitu karena sikap penerimaan dan kesiapan bertindak sangat erat kaitannya dengan proses pembentukan perilaku sesorang. Kesiapan bertindak tersebut mencakup kesiapan implementasi personal hygiene, sikap kepatuhan larangan, ketelitian atau kecermatan bekerja, dan sikap prioritas terhadap keamanan kerja.

Hasil analisis statistik deskriptif menunjukkan bahwa kategori pencapaian sikap keselamatan penjamah makanan di Warung Lesehan Malioboro termasuk kategori cukup baik. Ini bermakna bahwa internalisasi kesiapan personal hygiene, sikap kepatuhan larangan, ketelitian atau kecermatan bekerja, dan sikap prioritas terhadap keamanan kerja menunjukkan kategori yang cukup baik. Hasil ini berbanding lurus antara perolehan kategori sikap dan perilaku keselamatan mereka yaitu keduanya pada kategori cukup baik. Semakin tinggi kesiapan para penjamah makanan untuk bertindak sesuai dengan prinsip-prinsip keselamatan dan kesehatan kerja maka akan semakin besar perubahan perilaku keselamatan kerja mereka.
Proses internalisasi sikap keselamatan bagi para penjamah makanan juga perlu ditanamkan melalui penguatan pengetahuan mereka tentang keselamatan kerja. Karena pada hakekatnya pencapaian tahap akhir sikap dalam bentuk penerimaan dimulai dari perhatian dan pengertian. Kedua aspek ini yaitu perhatian dan pengertian sangat erat kaitannya dengan seberapa besar informasi yang mereka pahami mengenai keselamatan kerja di tempat kerjanya. Selain itu, studi sebelumnya menunjukkan bahwa pengetahuan mampu mempengaruhi sikap seseorang [33]. Dengan demikian, kegiatan pelatihan atau penyuluhan menjadi aspek penting dalam rangka membangun kesadaran mereka untuk membentuk sikap positif yang baik mengenai keselamatan kerja dan pada gilirannya akan membentuk perilaku keselamatan mereka.

\section{Faktor Motivasi Keselamatan Sebagai Prediktor Perilaku Keselamatan}

Hasil berikutnya dalam penelitian ini yaitu motivasi keselamatan secara langsung dan positif mempengaruhi perilaku keselamatan. Artinya, perilaku keselamatan para penjamah makanan di Warung Lesehan Malioboro dapat ditingkatkan dengan meningkatkan motivasi keselamatan pekerjanya. Hasil ini sama halnya dengan hasil studi sebelumnya [20], [21] yang menunjukkan bahwa motivasi keselamatan mampu memprediksi perilaku keselamatan pekerja. Temuan ini sangat masuk akal jika dikaitkan dengan teori motivasi, dalam teori motivasi keselamatan mengungkapkan bahwa motivasi merupakan kemauan seseorang untuk mengerahkan usaha untuk berperilaku selamat [24]. Dalam pemahanan ini, motivasi berperan untuk mengarahkan tindakan seseorang sesuai motif yang diharapkan.

Pada prinsipnya banyak cara untuk meningkatkan motivasi keselamatan seseorang dalam bekerja, salah satunya terjaminnya rasa aman dan nyaman ketika bekerja. Dorongan motif untuk bekerja secara aman dan nyaman akan mampu mengarahkan seseorang bertindak secara hati-hati untuk dirinya dan bahkan untuk dapat 
mempengaruhi orang lain agar bertindak secara aman. Selain itu, motif ini juga mampu mengarahkan kita untuk terlibat dalam kegiatan-kegiatan keselamatan kerja atau setidaknya memprioritaskan keselamatan dalam bekerja. Seperti halnya dalam penelitian ini, motivasi keselamatan para penjamah makanan diukur melalui beberapa indikator motivasi keselamatan seperti prioritas keselamatan, rasa keamanan personal, mengurangi resiko, kenyamanan, reaksi kolega, reaksi atasan.

Oleh karena itu, penting dilakukan penguatan motivasi keselamatan bagi para penjamah makanan ketika bekerja. Beberapa upaya yang dapat dilakukan oleh para pihak terkait seperti paguyuban atau pemilik restoran untuk memberikan penghargaan (reward) dan hukuman (punishment) bagi para pekerja yang mepriorotaskan keselamatan kerja. Seperti halnya yang disampaikan oleh Vinodkumar dan Bhasi (2010) bahwa upaya yang dapat dilakukan manajemen untuk memotivasi para pekerja yaitu dengan pemberian insentif, sistem reward atau penghargaan kepada para pekerja.

Secara garis besar, salah satu temuan ini menyoroti peran penting dari motivasi keselamatan dalam meningkatkan perilaku keselamatan yang baik terutama dalam konteks industri informal seperti para pedagang kaki lima (warung kesehan). Semakin kuat motivasi keselamatan para penjamah makanan di Warung Lesehan Malioboro maka akan semakin besar kemauan untuk bertindak secara aman.

\section{Kesimpulan}

Hasil studi ini mengungkapkan bahwa gambaran deskriptif pengetahuan, sikap, motivasi, dan perilaku keselamatan kerja penjamah makanan di Warung Lesehan Malioboro masuk kategori cukup baik. Temuan lainnya, faktor pengetahuan, sikap, dan motivasi keselamatan secara parsial memiliki pengaruh terhadap perilaku keselamatan kerja. Selain itu, secara simultan faktor pengetahuan, sikap, dan motivasi keselamatan memiliki pengaruh signifikan terhadap perilaku keselamatan kerja penjamah makanan. Terakhir, ketiga variabel independen meliputi pengetahuan, sikap, dan motivasi berkontribusi memberikan pengaruh sebesar $66 \%$ terhadap pembentukan perilaku keselamatan kerja para penjamah makanan di Warung Lesehan Malioboro.

Hasil studi ini memberikan implikasi pada pelaku usaha kuliner agar dapat memperhatikan penguatan kapasitas pengetahuan, sikap, dan motivasi para penjamah makanan melalui program-program edukasi. Selain itu, pengembangan program edukasi juga tidak hanya memprioritaskan peningkatan kapasitas pengetahuan, namun juga perlu melibatkan penguatan kapasitas sikap dan motivasi keselamatan dalam muatan materi edukasinya.

\section{Saran}

Hasil studi ini perlu dikembangkan untuk mendapatkan mekanisme penguatan perilaku keselamatan kerja dengan melibatkan faktor pengetahuan, sikap, dan motivasi keselamatan kerja. Rekomendasi penelitian dengan menggunakan analisis Structural Equation Modeling (SEM) sangat disarankan. Analisis SEM mampu menjawab bagaimana membangun model peningkatan perilaku keselamatan dengan melibatkan faktor pengetahuan, sikap, dan motivasi keselamatan atau bahkan dengan menyertakan faktor lain yang diyakini memiliki pengaruh besar.

\section{Daftar Pustaka}

[1] S. Buchanan et al., "Occupational injury disparities in the US hotel industry," Am. J. Ind. Med., vol. 53, no. 2, pp. 116-125, 2010.

[2] International Labour Organization, Keselamatan dan Kesehatan Kerja Sarana untuk Produktivitas (Pedoman Pelatihan untuk Manajer dan Pekerja). Jakarta: International Labour Office, 2013.

[3] M. T. Newaz, P. Davis, M. Jefferies, and M. Pillay, "The psychological contract: A missing link between safety 
climate and safety behaviour on construction sites," Saf. Sci., vol. 112, pp. 9-17, 2019.

[4] P. Zhang, N. Li, Z. Jiang, D. Fang, and C. J. Anumba, "An agent-based modeling approach for understanding the effect of worker-management interactions on construction workers' safety-related behaviors," Autom. Constr., vol. 97, pp. 29-43, 2019.

[5] B. H. W. Guo, T. W. Yiu, and V. A. González, "Predicting safety behavior in the construction industry:

Development and test of an integrative model," Saf. Sci., vol. 84, pp. 1-11, 2016.

[6] F. Guennoc, C. Chauvin, and J.-C. Le Coze, "The activities of occupational health and safety specialists in a highrisk industry," Saf. Sci., vol. 112, pp. 71-80, 2019.

[7] T. K. Courtney, Y. H. Huang, S. K. Verma, W. R. Chang, K. W. Li, and A. J. Filiaggi, "Factors influencing restaurant worker perception of floor slipperiness," J. Occup. Environ. Hyg., vol. 3, no. 11, pp. 592-598, 2006.

[8] HSE, "A recipe for safety: Health and safety in food and drink manufacture," 2015. [Online]. Available: http://www.hse.gov.uk/pubns/books/hs g252.htm. [Accessed: 11-Dec-2018].

[9] ILO, "Restaurants - ILO Encyclopedia of Occupational Health and Safety," 2011. .

[10] R. W. Lent et al., "The role of contextual supports and barriers in the choice of math/science educational options: A test of social cognitive hypotheses," J. Couns. Psychol., vol. 48, no. 4, pp. 474-483, 2001.

[11] A. Silla and V.-P. Kallberg, "Effect of railway safety education on the safety knowledge and behaviour intention of schoolchildren," Eval. Program Plann., vol. 55, pp. 9-16, 2016.

[12] C. Wang, C. Xu, J. Xia, and Z. Qian, "The effects of safety knowledge and psychological factors on self-reported risky driving behaviors including group violations for e-bike riders in China," Transp. Res. Part F Traffic Psychol. Behav., vol. 56, pp. 344-353, 2018.

[13] F. Kalua, "The Relationship between Knowledge, Attitude and Practices Ofcare Givers and Food Hygiene in Day Care Centers," Technikon Pretoria, 2001.

[14] W. Ko, "The relationship among food safety knowledge, attitudes and selfreported HACCP practices in restaurant employees," Food Control, vol. 29, no. 1, pp. 192-197, 2013.

[15] A. Hedlund, K. Gummesson, A. Rydell, and I. Andersson, "Safety motivation at work : Evaluation of changes from six interventions," Saf. Sci., vol. 82, pp. 155-163, 2016.

[16] D. N. Maulidhasari, "Faktor-Faktor Yang Berhubungan Dengan Perilaku Berbahaya (Unsafe Act) Pada Bagian Unit Intake PT.Indonesia Power Unit Bisnis Pembangkitan (UBP) Semarang," Universitas Dian Nuswantoro, Semarang, 2011.

[17] S. Notoatmodjo, Pendidikan Dan Perilaku Kesehatan. Jakarta: Rineka Cipta, 2003.

[18] B. Endroyo, "Faktor-faktor yang berperan terhadap peningkatan sikap keselamatan dan kesehatan kerja (k3) para pelaku jasa konstruksi di semarang," J. Tek. Sipil dan Perenc. UNNES, vol. 12, no. 1993, pp. 111120, 2010.

[19] S. P. Robbins, T. A. Judge, B. Millet, and M. Boyle, Organisational Behavior, 7th ed. Australia: Pearson Education, 2013.

[20] R. M. Choudry, D. Fang, and H. Lingard, "Measuring Safety Climate of a Construction Company," 2009.

[21] M. N. Vinodkumar and M. Bhasi, "Safety management practices and safety behaviour: Assessing the mediating role of safety knowledge and motivation," Accid. Anal. Prev., vol. 42, no. 6, pp. 2082-2093, 2010. 
[22] K. Dartey-Baah, "Job satisfaction and motivation: Understanding its impact on employee commitment and organisational performance," Acad. Leadersh., vol. 8, no. 4, 2010.

[23] S. Notoatmodjo, Ilmu Perilaku Kesehatan. Jakarta: Rineka Cipta, 2014.

[24] A. Neal and M. A. Griffin, "A study of the lagged relationships among safety climate, safety motivation, safety behavior, and accidents at the individual and group levels," J. Appl. Psychol., vol. 91, no. 4, pp. 946-953, 2006.

[25] D. P. Shin, H. S. Gwak, and D. E. Lee, "Modeling the predictors of safety behavior in construction workers," Int. J. Occup. Saf. Ergon., vol. 21, no. 3, pp. 298-311, 2015.

[26] C. Chen and S. Chen, "Measuring the effects of Safety Management System practices , morality leadership and selfefficacy on pilots ' safety behaviors : Safety motivation as a mediator," Saf. Sci., vol. 62, pp. 376-385, 2014.

[27] E. Hafrida, "Kuesioner penelitian pengaruh faktor personal dan manajemen K3 terhadap tindakan tidak aman pada pekerja di PT. Inti Benua Perkasatama Dumai," Repos. Institusi Sumatera Utara, 2015.

[28] I. Mohammadfam, F. Ghasemi, O. Kalatpour, and A. Moghimbeigi, "Constructing a Bayesian network model for improving safety behavior of employees at workplaces," Appl. Ergon., vol. 58, pp. 35-47, 2017.

[29] M. A. Griffin and A. Neal, "Perceptions of safety at work: a framework for linking safety climate to safety performance, knowledge, and motivation.," J. Occup. Health Psychol., vol. 5, no. 3, pp. 347-358, Jul. 2000.

[30] G. Sax, Principles of education and psychological measurement and evaluation, 2nd editio. Belmont, California: Wadsworth Publishing
Company, 1980.

[31] J. F. Hair, W. C. Black, B. J. Babin, and R. E. Anderson, Multivariate data analysis: A global perspective, 7th. Upper Saddle River: Pearson Prentice Hall, 2010.

[32] I. Ghozali, Aplikasi analisis multivariate dengan program IBM SPSS 19. Semarang: Badan Penerbit Universitas Diponegoro, 2011.

[33] P. G. Schrader and K. A. Lawless, "The knowledge, attitudes, \& behaviors approach: How to evaluate performance and learning in complex environments," Perform. Improv., vol. 43, pp. 8-15, 2004.

[34] S. Notoatmodjo, Promosi Kesehatan dan Ilmu Perilaku. Rineka Cipta, 2007. 